\title{
Transmitters of Hadith of Abu al-Qasim al-Khoei in General Reliability
}

\author{
Mohammad Hadi Mofateh ${ }^{1} \&$ Seid Mahdi Sadati ${ }^{1}$ \\ ${ }^{1}$ University of Qom, Iran \\ Correspondence: Mohammad Hadi Mofateh, University of Qom, Iran. E-mail: mhmofateh@yahoo.com
}

Received: November 9, 2016

Accepted: November 19, 2016 Online Published: November 30, 2016

doi:10.5539/jpl.v9n10p95

URL: http://dx.doi.org/10.5539/jpl.v9n10p95

\begin{abstract}
Ayatollah Khoei expressed various views by other scholars besides expressing his views on general reliabilities. Concerning People of Consensus, he believes that transmission of hadith does not mean all the hadiths narrated by each of people of consensus by Imams, but the mursal hadith or the hadith narrated by the poor narrator is acceptable, expressing the majesty and position of hadith. Concerning An Al-Saghat, he believes that Ja'far ibn Bashir has narrated from the poor narrators such as Saleh bin al-Hakam and Abdullah bin Mohammed Jaefi, however how it can say that he has been being narrated from reliability. Ahmad ibn Muhammad ibn Abi Nasr as narrated by Shaykh Tusi is among three jurists who have been being narrated from reliability. Abu al-Qasim al-Khoei has mentioned name of 115 Sheikhs among which 53 members are reliable and others are unknown, nonsense or poor. He said that there is no accompaniment between accompany and reliability, as we do not know the prophet's accompanions just due to their accompaniment with him. Seeking for mercy and forgiveness are the assignments recommended in religion, mentioned that it can seek forgiveness for the unfaithful believers. Therefore, if the people like Sheikh Mofid or Sheikh Sadough seek forgiveness for a person, this does not mean their reliability.
\end{abstract}

Keywords: transmitters of hadith, general reliability, People of Consensus, Abu al-Qasim al-Khoei's views

\section{Introduction}

The main purpose of Ilm ar-rijal is to evaluate and criticize the hadith that recognition of the narrators' situation is the requirements of this purpose to know whether they have the special conditions for maintenance and narration of hadiths or not; Whether they have been adjusted or not; reliability of narrators of hadith is in two ways: certain reliability and general reliability. If the reliability comes certainly about one or two narrators, this type of reliability will be called with certain reliability, e.g. infallible stipulates the reliability of a narrator. Yet general reliability implies that a group of narrators becomes reliable with a special criterion such as reliability "People of Consensus". Criticism on general reliability including Mashayekh al Saghat, People of Consensus, Mashayekh al ejazeh, multiplicity of narration, advocacy of the viewpoint of infallibility, owner of book and originality and others have been examined by the scholars specialized at Ilm ar-rijal. Among scholars, views of Ayatollah Khoei have been taken into account in this study. Ayatollah Khoei has not known any of these as a reason for the general reliability. The famous general reliability in views of Ayatollah Khoei include Kamil al-Ziyarat and Nawader al-Hekmah Rejal in which he has expressed his certain views.

\section{Research Method}

The present research is a descriptive-analytical research conducted via library instrument, computer networks and information databases, quranic and hadith science software.

\section{Study on General Reliability}

\subsection{People of Consensus}

Ayatollah Khoei has stated in the book "Mu'jam rijāl" that the first one who has discussed on people of consensus has been the one who has mentioned in the book "'(Khoei, 1994, vol. 1, p. 59). Rejali evidences indicate that the Abu Omar koshi for the first time in his rejal mentioned the issue of "People of Consensus"(Nouri, 1408 AH, vol 3, p. 757). Abu Omar koshi in three parts in his book entitled "companions of Imam Baqir (A.S.) and Imam Jafar ibn Muhammad al-Sadiq, companions of Imam Sadiq (AS), companions of Imam Musa al-Kazim(a.s.) and Imam Reza(a.s.)" have mentioned consensus of shia scholars on knowing the 
narratives of a group of companions proper and right. He has stated that Imamieh have reached a consensus about approving their proper narratives on subscription to their speech and acknowledged their jurisprudence (Koshi, author, Tusi, 1968, vol 2, p. 673). Further he has stated about the third group, i.e. companions of Imam Musa al-Kazim(a.s.) and Imam Reza(a.s.) in this way:

Without justice being a condition in narrators who narrate of him, even they narrate from famous narrators to the debauchery or situation. Let alone they narrate the hadith by sent document, all their citations are proper and their narrations are considered issued from the Imams (Khoi, 1993 Sun, vol. 1, p. 62).

Ayatollah Khoi says, this is not an explicit phrase in the word stylish and it does not even appear in it. Therefore, what is true of this is a story. However, just as likely, it has the irony of consensus possibility on justice and truth. Unlike those who have not quoted a consensus on justice.

Here is something that remains to be said: the claim of consensus on considering right what is true of the congregation to stories authority claims would not return as worshiping. "Because consensus to a unit new is not ultimatum as the owner of tools has accepted." Indeed, to the claim that these are not narrating except from reliable. Therefore, their chosen stories will be trusted, although the tools will be unknown or nonsensical. However, this promise is certainly wrong, and then it's will from the Word style is not likely. If we accept that, he wills that so the claim is invalid, because the people of consensus in a number of cases have narrated from the weak that in our book, it came in their translations. (Khoi, 1993 Sun, vol. 1, p. 63)

In the word style, there are two possibilities:

- The objective is accurate quotes and anecdotes to count them; it means we accept the people of consensus that have been narrated in all the narrations of Imams (AS). In other words, we consider them trustworthy. In this case, the people of consensus will be securitized the public. A number of scholars made this decision. According to this concept, the people of consensus would be unreliable component, rather than any narrations that they have quoted will be considered correct, even if it is chosen or poor.

- The purpose of considering their enumerate proper, i.e., we consider all the traditions of the people of consensus that had quoted correctly and issued by the Imams, even if the narrative has no binding document, or other accurate conditions, such as justice and faith of the narrator. In this case, the position higher than securitized will be proven for the people of consensus, because this claim means that, not only consensus are trustworthy and righteous, but also they are at such a high level of reliability, that do not narrate the traditions except the narrations issued by the imams. Although in superficial look at the document of the traditions, we consider them lack of authenticity. Some Shiite scholars also agree with this decision. (Sobhani, 1425, p. 188-186)

Mohades Noori is one of those scholars who have insisted on this theory. (Noori, 1408, vol. 3, p. 758)

Ayatollah Khoi says:

The supervisor's speech is not that all the traditions, each of the people of consensus had quoted from the Imams will be correct. Even the Morsel narration, or cited by the narrator will be weak, or anonymous, but, the purpose is the authenticity of the grandeur and their status, and it is consensus on their jurisprudence and acknowledge in their narrations, it means there are not accused to false in the news and narrations. (Khoi, 1993 Sun, vol. 1, p. 61)

Ayatollah Khoi believes that the relationship that has been given to the parties, which Quoted documents and Documents consider it the same, is not correct, because, if that was from the Muslim, it should be seen in the words of scholars. Another drawback that Ayatollah Khoei cites is that even if Sabutan can be made that these people are La Yaron and La Yarsalon except as trustworthy. However, positively it is not acceptable because we have no way to check all the Marvi and elders of the people. Even the people themselves have not claimed that only have cited from the reliable. Therefore, the best thing that can be said is that scholars have not found as far as they access that these people cite from non-trustworthy.

Then Ayatollah Khoei refers in cases of violation that Ibn Abi Umayr and Safwan, Bazanty, and his like have quoted from unreliable.

However, about the Ibn Abi Amir, few cases are noted:

The first violation, Safwan Ibn Yahya and Ibn Abi Umair have narrated from Ali Ibn Abu Hamza several times. In the case of Ali Ibn Abi Hamza in scholars we read that Ali bin Hassan bin Fazal have said about him that he is a liar and accursed.

The second violation is Yunus bin Zabian that Sheikh has narrated in refinement and Istibsar to Sandesh of Safwan and Ibn Abi Umair that they have narrated from Yunus bin Zabyan. Sheikh and Najashi both have 
weakened him.

\subsection{Trustworthy Elders}

From a group of Hadith elder and famous narrators are trustworthy elders and the two things would have been used:

1) All those who Trustworthy elders have narrated would be trustworthy;

2) As their Documents are acted, the Marasyl (= morsel narration) will be implemented. It seems that Sheikh Tusi for the first time, has been discussed this issue. He says that if one of the two narrators will be (= the people from quoting documents) and the other will be Mursal (= from deleting documents), we look at Mursal, if it is one of those who we know; they do not quote only from trustworthy traditions, masnad narrations do not prefer on him. (Toosi, 1417, vol. 1, p. 386) .Ayatollah Khoi has said in this case: from what was said to Sobutash in public securitized, narrated by Safwan, or Ibn Omair, or Ahmad Ibn Mohammad Ben Abi Nasr, and like him, who has said, they do not narrate except from reliable forwarding. So, their Quated documents and Masanid will be charged. However, intermediaries are unknown or vague. Ayatollah Khoi states that sheikh has said the principle of the claim. In the book of Adeh, in the end of the argument, he said the news, when one of the two narrator is masnad, and the other is morsal, the Hadith Mursal will be paid attention, so if it is from someone who knows that he does not send, unless the trustworthy that he is trusted, so there is no preferred in mansand news on morsal, that's why, being equal between what they narrate, Muhammad Ibn Abi Umair, and Safwan Ibn Yahya, and Ahmad Ibn Muhammad Ibn Abi Nasr, and others are known as unreliable that they do not narrate and send unless the person who is trustworthy ... Ayatollah Khoi says: the claim is false. Verily, this claim is Sheykh's ijtihad and has deduced it from Sheikh is believed to equal Sheikh Companions, among them Mrasyl these and other Musnads. (Khoi, 1993 Sun, vol. 1, p. 61)

The Sheikh Tusi in some cases of purification and Istibsar has rejected equating Quated documents of Ibn Abi Amir with Musnads, has rejected his traditions. For example, after the narration of Muhammad Ibn Abi Amir from Imam Sadiq (AS) in which kor has declared 600-pounder: "The first disadvantage is that the narrative is morsel and has no document" Sheikh Almofid, 1985, vol. 1, Page 43

Ayatollah Khoi also believes that.

He has entered four significant drawbacks about the theory of equating Quated documents of Ibn Abi Amir with Quated documents as follows:

- The claim of equating has been raised only from the Njashy and then Sheikh and later Rajaliyun to follow them have mentioned and if that were common among the ancients, should be seen in their resources.

- On the assumption that we accept such equality, it will not mean that the trustworthy companions have acted quoted documents because Ibn Abi Amir has quoted from Saghe; perhaps this is due to a rule among the ancients who believed that when debauchery of Reporting Imam does not appear, a narrative could be functioned. Even if his authenticity does not prove.

- The claim that the likes of Ibn Abi Umair only quote from unreliable, cannot be proved because they themselves have not acknowledged in their work in such a way that they have eliminated documents and some of the narrators are unknown so that their reliable or not reliable will be proven.

- This rule is practically violated, namely Muhammad Ibn Abi Amir has narrated traditions that are weak. Ayatollah Khoi has named four of the weak narrators as Ali Ibn Abu Hamza Btayny, Yunus Ibn Zbyan, Ali Ibn Hadid and Hussein bin Ahmad Manqary. In addition, he has pointed traditions in the Four Books. (Khoi, 1993 Sun, vol. 1, p. 65)

As Ayatollah Sobhani have said, if we consider the first triple problems unfinished, fourth problem is not responsive because, how in spite of the narrative from poor people, it can be claimed that, Ibn Abi Amir, or other unreliable masters do not quote from non-sage (Sobhani, 1425, p. 233)

\section{Mashayekh Ejazeh}

A group of narrators of hadith have allowed principle narrate, or Hadith Book to individuals that are remembered as Mashayekh Ejaze and since, letting tradition, in the past, of having a person of rank a long, Hadith indicates that, therefore, it is said: Mashayekh Ejaze is considered unreliable and have no need for a new tosigh, and even if, their name has not come in rejali resources, they have been sentenced to authenticity. Accordingly, Mashayekh Ejaze, such as Koleini, Sheikh Saduq, Sheikh Tusi, etc., all will be reliable. Ayatollah Khoi considered this view wrong. His reasons as follows: 
Mashayekh Ejaze is not supposing acceptance, and their Vaseghan is not above the people of consensus. However, how the scholars of Rijal, themselves have found it necessary that to express in the literature concerning the authorities, the people of consensus and reliability of their evidence, but have not expressed the authority of the elders, although trustworthiness for general?

Among Sheikh, to be allowed is not accompanied by authenticity, let's tradition of tolerance like other ways, such as singing, reading, etc. means that the narrator is honest in receiving the hadith, or book of his tradition, not necessarily Sheikh his hadith is reliable.

Some of the elders' permission has no authority, and Negus has weakened them. (Khoi, 1993 Sun, vol. 1, p. 73)

\section{Attorney of Imam (AS)}

It is said that representing Imam (AS) is a proof of authenticity, because Imam (AS) will declare a person as his lawyer that has reliable, and fair. Fans also have appealed this decision to the narrative saying:

Hassan bin Abdul Hamid said: I suspect the work of Hajez "deputy of Imam Mahdi (AS)", then I packed together, and moved to the camp that this message came to me "about us and our substitute is no doubt, what you have, deliver to Hajez Ibn Yazid "(Kleene al-Razi, 1996, vol. 1, p. 14)

Control is that part of the speech of Imam (AS) that he said: "On our successor there is no doubt", i.e. the reliability, fairness and integrity of him should not question.

Ayatollah Khoi has considered this theory flawed for the following reasons:

- There is no accompanied between the law and justice, because Balajma is permissible in unfaithful substituent. Wise in finance, those who entrust their work to ensure their trustworthiness, but reliability and trustworthiness in protecting property other than justice.

- The invoked narrative is flawed in two respects:

A. Narrated by Hasan bin Abdul Hamid is weak in terms of evidence. In addition, if his weakness is not fixed, it is at least unknown.

B. Narration refers to those who are vicar Imams: it means it includes the deputies and ambassadors and does not include anyone who holds power of attorney authority in a particular field. The implication of narrative is unfinished. (Khoi, 1993 Sun, vol. 1, p. 72)

\section{Benno Fazal}

Benno scholars include some of the narrators that: Ali Bin Hassan of Ali Ben Fazal and his brothers Ahmed and Mohammed and their father, Hassan bin Ali bin Fazal, despite the strength of belief in the beginning, they perverted beliefs and inclined Fathiye sects. (Alkhaqany, 1404 AH, p. 215)

Considering the fact that during the Endurance, many traditions were quoted and heard of the Imams, Shiite scholars have asked Imam Hasan Askari (AS) about citing narrations, and Imam said: "follow their narrations, but release their views". (Alnoori Altabaresi, 1996 Sun, vol. 4, p. 269 and p. 450, temperamental, SB 1993, vol. 1, p. 67)

It is also reported that Sheikh Abulghasem Nobakhti (ambassador of Imam Mahdi (AS) has been asked that what happen to the books of Ibn Abi Alazaqer after his curse by the Imam (AS) while our home is full of their books?

He replied: "I give the same answer about their book, as Imam Hassan Askari (AS) gave on the books of Isaiah scholars..". He noted the previous version. (Toosi, translated by Mojtaba Azizi, 2008, p. 239

According to this narrative as declared by the Imam (AS), Hadiths of Benno Fazal is operable although they have corruption beliefs.

Ayatollah Khoihas two explanations on the argument:

- Narrated is weak and unreliable due to Abdullah Kofi in the document.

- Narrative implies the claim is also skewed because the narrative is referred to the fact that corruption of belief after endurance does not harm the authenticity and validity of traditions that have been quoted at the right time of opinion, rather than in the sense that all the narrations, both traditions before departure, or after ideological deviation that are quoted, or traditions which posts or weakness is evidence, are proof (Khoi, 1993 Sun, vol. 1, p. 71).

\section{Authenticity of Documents of Interpretative Narrations of Ali bin Ibrahim}

Ali bin Ibrahim Qomi is the author of Qomi interpretation that Naashi has said about him, he is reliable in the 
hadith, he is trusted, he has correct religion, he has heard many traditions, and has written many books. (Alnajashi, $1416 \mathrm{AH}, 260$ varieties of 680)

It is argued that the authenticity of those who has been argued the traditions interpretation of Ali Ibn Ibrahim, to what is mentioned in the introduction to his book, the promise which says, "and we are aware of and we're providing what has come to us and our teachers and unreliable have narrated (Rawah Mashaykhna Vasqatna) to whom Allah has obligated obeying him and his leadership and practice will not be accepted but because they do "(Qomi, Ali bin Ibrahim, 1984 Sun, 1 / 4).

Ayatollah Khoi in this case says:

In these words, Ali bin Ibrahim, said in the introduction to his book, Rawah Mshaykhna and Sqatna has apparent implication to that he has not narrated in his book, but unreliable. But the owner of the utility in Faedeh Alsadade in his book on the testimony of a large number of scholars, referred to the accuracy of books and its kind and its Tavaser and Sobutash from his author and Sobut of traditions of Ahl al-Bayt (AS) has used, that all of those, in Ali bin Ibrahim tradition in which leads to the infallible (as) Ali bin Ibrahim testified to their authenticity. Since Sheikh Hurr Ameli has said, Ali bin Ibrahim also has testified to the proven traditions of interpretation, that the traditions have been narrated from the unreliable from the Imams (AS).

Ayatollah Khoi states, what Sheikh Hurr Ameli has used is correct. Verily, Ali bin Ibrahim, to what it is saying, has proven the accuracy of its interpretation, and the narration is constant and has been issued of the saints. And the traditions has reached from Shia by professors and unreliable, and that is why there has no incentive that we securitized to the elders immediate Ali bin Ibrahim, those that Ali Ibn Ibrahim has narrated without intermediaries as some rejalion have thought. (Khoi, $1993 \mathrm{~S}: 1 / 49$ )

\section{Results of Discussion}

1) Study and compare views of Abu al-Qasim al-Khoei with other scholars

2) Express practices of Abu al-Qasim al-Khoei and the views opposite to his beliefs

3) Collect Rejal practices and its effects in judicial discourses

\section{Review}

- The narrator of Qomi interpretation is a person named Abolfazl Abbas Ibn Muhammad Ibn al-Qasim, who is a disciple of Ali bin Ibrahim. In addition, he is unknown and in books of Rojali, there is no praise from them.

- The existing interpretation is not belonged to Qomi alone, but it is a combination of what Ali Ibn Ibrahim has dictated to his disciple and what his pupil has narrated of Abu Jarvd from Imam Baqir (AS).

- Interpretation include of the narrators that the promise to Vasaqtshan is not correct, such as Yahya bin Aktham and others

\section{Narrators of Navaderalhekmah Book}

Navaderalhekmah book is including renowned Shiite books and Muhammad Ibn Ahmad Ibn Yahya is known as the owner of the book.

Another feature of the Navaderalhekmah book is that it is the source of many other Shi'ite books and stories contained in it, has gradually found its way into other books, and Shi'ite scholars have benefited from it.

Four Books owners have also provided their own books from this collection and other writings of the companions of the Imams (AS).

For example, Sheikh Saduq that considered the book "Man La Yahzer al-Faqih" an argument between himself and God, at the beginning of his book, he has introduced one of his sources in Navaderalhekmah of Muhammad Ibn Ahmad Ibn Yahya. (Saduq, 2011 AH, vol. 1, p. 4)

More interestingly, the Ibn Walid has recognized this book and has only selected some exceptions.

Sheikh Saduq said about the credibility of this book: what Muhammad bin Ahmad bin Yahya in his comprehensive (rare book) has said in the meaning of visual (seeing the Lord) is true, and no one can deny unless the denial of truth or ignorant to truth. (Saduq, 1398 AH, p. 120)

Muhammad Ibn Ahmad Ibn Yahya Bin Omran al-Ash'ari professors have argued to what Negus and Shekh have expressed in his translation that Muhammad Ibn Hasan alWalid has been the exception. The traditions of Muhammad Ibn Yahya have narrated from the congregation. They have pointed out his translation and the 
number of twenty-seven people. (Alnjashy, 1416 AH, p. 348, the 939, and Sobhani, 1425 AH, p. 292)

Abul Abbas Ibn Noah and Sheikh Saduq have accepted all cases except Mohammed bin Isa bin Obaid, because he was righteous and trustworthy (Alnjashy, $1416 \mathrm{AH}, \mathrm{p} 348$ ).

The late Ayatollah Khoei said: "Verily Ibn Walid trust or other of former elder, let alone a great one late on narrative and narrative authenticity of his sentence does not indicate the reliability of the narrator or his goodness, because it is likely that the judge has trusted him based on "authenticity Aldalh" to his narrates and know all believers traditions as debauchery in case of lack of authority. The basis is useless for someone that knows in authority, the reliability or narrator necessary. On the other hand, we see that Ibn Walid and his older counterparts have corrected its accuracy or trust of the narrative without arguing the narrator's authenticity. Saduq has also adherence in the correction and non-correction to comply himself from his mentor- Ibn Walid. "(Khoi, 1993 Sun, vol. 1, p. 74). The rejection of Ayatollah Khoi is the principle of the rule. He did not know Ibn Walid and others saying, testify to the authenticity of Sheikhs Mohammed bin Ahmed, but counted it as a correction of his traditions, also on the basis for the ancients, that is not accepted by later, and finally if he has accepted its authenticity, he has considered it according to "authenticity Aldalh".

\section{Roye an Alsaghat and Rava Ane}

Negus talked about Ja'far Ibn Bashir: "Anne, I Kan Z·had Ashabna and Badhm and Nsakhm and trustworthy, as Alsqat and Rowe on Nh" (Alnjashy, 1416 AH, vol. 1, p 298, figure 304)

Ja'far Ibn Bashir liked asceticism and worshipping, ritual, and reliable, he quoted from unreliable narration and unreliable narratives have narrated from him. By resorting to the words, they wanted to prove reliability both in-class of elders Ja'far Ibn Bashir and his students. Some, including Haji Noori, according to the statement of Negus are attached to this person that "as trustworthy" Therefore, Haji Noori claimed, whoever, Jafar quoted from his narrative, is reliable. (Optics, 1408, vol. 3, p. 777

The late Mr. Khoi had two forms of the expression indicating that one cannot conclude with Negus phrase that Ja'far Ibn Bashir "except as trustworthy"

\subsection{The First Drawback}

Negus statement that said "the Alsqat as" by no means implies no restriction, if it is said that Ja'far Ibn Bashir narrated unreliable does not mean that he did not narrate from non-reliable. This phrase is different with Tells about trustworthy ", because if anyone quoted often from unreliable narration he can be said " Tells about trustworthy ", and we even cannot just tell about Imams and only unreliable have quoted stories because there are many cases that Zaf have narrated from the imams, so when the Imams cannot say that just unreliable have narrated from them, for others a fortiori should be noted that was not like this, only unreliable have quoted stories from them, so it become clear that the sentence «Rouen him» explains that often unreliable have quoted stories of him not that because only unreliable have quoted stories about him so since this statement does not imply the arrest, the first sentence " Narrated from trustworthy" was not the implications of the arrest. Therefore, due to this, we cannot say the Negus that "Narrated from trustworthy "implies that all elders will be Ja'far Ibn Bashir. (Khoi, 1993 Sun, vol. 1, p. 71

For others, a fortiori, it must be said, that this is not that only unreliable have narrated their story, so it appears, the phrase " Narrated from him," is the evidence that often unreliable have quoted his stories, not just unreliable have quoted from his narrative, then as the phrase does not imply the arrest, the first sentence, "Narrated from trustworthy", also does not imply the arrest. Therefore, according to this, we cannot say, the Negus that "Narrated from trustworthy "implies that all elders will be Ja'far Ibn Bashir trustworthy. (Khoi, 1993 Sun, vol. 1, p. 71)

\subsection{The Second Drawback}

There are cases of violation that prove Ja'far Ibn Bashir has cited narrative from the weak and despite Zaf, Haji Noori words that wanted to use the Negus word and Jafar Ibn Bashir authority of the elders, will be violated. Including those Ja'far Ibn Bashir has quoted is Saleh bin Hakam which has been weakened by the Negus, also Ja'far Ibn Bashir has also narrated from Abdullah bin Mohammed Jofy that this person has been weakened by the Negus. (Alnjashy, 1416 AH, vol. 1, p. 315)

Thus, according to the two forms of drawbacks, we cannot say about Ja'far Ibn Bashir that, "Not only tells about confidence."

\section{Authenticity of the Companions of Imam Sadiq (AS)}

Including a general assessment of reliability is the reliability of a large number of the companions of Imam Sadiq 
(as), in the words of Shaykh Mufid (d. 413 AH). The source of the securitized is a passage from the Book of Guidance, which, the authenticity of four thousand of the companions of Imam Sadiq (as) can be picked up and a number of scholars have accepted it.

And none of the scholars of the family, to the extent that it has been narrated, have not quoted from the others, and none of the works owner and news carriers, which benefited from Hazrat, have not benefited from others because the people of Hadith that have gathered the name of great man's unreliable narrators, with differences of opinion and speech, their number reaches to four thousand persons. (Almofid, $1413 \mathrm{AH}$, vol. 2, p. 179)

Haji Noori has argued in the eighth benefit of Mustadrak Alvasayel. (Noori, 1408, vol. 7, p. 69)

Sheikh Tusi kindness of God, with the words "It has reached the end" stipulates that Ibn Oghde has collected all the companions of Imam Sadiq (as). Then he said that I quote what Ibn Oghde has collected. But because Ibn Oghde has mentioned the companions of Imam Sadiq (as), then I will quote also the people of other Imams. (Al-Tusi, 1415 AH, p. 17)

The late Mr. Khoi said:

Just because someone's name is stated in the words of Sheikh and Negus as a companion of Imam Sadiq (AS) is not an evidence of reliability, because the purpose of those that said the companions of Imam Sadiq is 4000 trustworthy - in the words cited of Shaykh Mufid, Ibn Shahr Ashub and Tabarasi said that the companions of Imam Sadiq (as) that are 4,000 persons reliable, is nothing but two things:

It means that the companions of Imam Sadiq (as) is 4000 persons and all of them are reliable, This is similar to what the public talk about the companions of the Prophet (PBUH), because the public believe that all companions of the Prophet (PBUH) are fair.

Or it means that the companions of Imam Sadiq (as) are more than 4000 persons, but only 4,000 of them are trustworthy.

The late Mr. Khoi said:

Each of these two possibilities that are considered can be invalid because in the first assumption, it is claimed that the companions of Imam Sadiq (AS) are 4000 persons and all of them are reliable, while, this claim is not acceptable because, at the time of Imam Sadiq (as), there were people that their authority cannot be ruled, for example, Mansur Davaniqi or like Abraham Ibn Abi Hob Harith Ibn Umar Basri and his kind, that the Sheikh has weakened them.

However, the second assumption was that, the companions of Imam Sadiq (as) are more than 4000 persons but among them, 4,000, are reliable, the premise is that:

First: what Ibn Oghde has said about the number of the companions of Imam Sadiq (AS) were 4,000 people, requiring the likely is the presence of other people among the companions of Imam Sadiq (AS), while, invoking the principle is reasonable in the words of Sheikh Mofid and Ibn Shahr Ashub returns to the book of Ibn Oghde.

Second, those individuals that Sheikh has called them as companions of Imam Sadiq (as) is not clear that his purpose is their authenticities but he only wanted to express their translations and biographies.

Considering the above drawbacks, Haji Noori claim is not correct, and then the result is that the companion of Imam Sadiq (AS) is not the mark of authenticity. (Khoi, 1993 Sun, vol. 1, p. 55)

\section{Other General Trustworthiness}

Company of Imam (AS), a book compilation, or sending mercy principle is one of a declared, and a plurality of the Imams (as) traditions is including titles that have been presented as general trustworthiness. (Khoi, 1993 Sun, vol. 1, pp. 74-75)

The company of Imam:

According to some claims, his companion proves the authenticity of a person, while there is not accompanied between a company and the authority, as we all do not know all companions of the Prophet (PBUH) for his companionship with Hazrat.

Mercy and forgiveness:

Mercy and forgiveness also are the things that the law has recommended and as it is suitable, it has asked for forgiveness for the unfaithful believers. As for famous people to debauchery, like Sayed Ismail Hemyari, or Mohammed bin Abdullah bin Bohlul have been asked for penitence although the lack of reliability was clear. (Khoi, 1993 Sun, vol. 1, p. 78) 
A plurality of traditions of the infallible:

The multiplicity of narratives from infallible indicator has been considered of trustworthiness in this respect that in some hadith that says: (Kulayni al-Razi, 1996, vol. 1, p. 50, Hurr al-Amel, without so, vol 27, p 150) Know the dignities of persons with us on the basis of which they have quoted about us. "

While these traditions are weak in terms of evidence and in terms of the implications are principles of reliable narrators that have been considered hadith refers to the presence of the Infallible Imams (AS). The fake narrators may be narrated Hadiths more than the reliable narrators of Imams (AS) Hadiths were narrated. (Khoi, 1993 Sun, vol. 1, p. 74. 75)

\section{Conclusion}

1) The purpose of speech in relation to the people of consensus is the authenticity of the grandeur and their status, and the jurisprudence and acknowledge have been consensus in narrations that they are not accused to be false in the news and narrations.

2) The claim that the likes of Ibn Abi Amir, only quoted the unreliable, cannot be proved because they themselves, in such a way, have not conceded in their work. How to face a version of the weak, it can be claimed that, Ibn Abi Amir or other unreliable masters did not quote from Non-trustworthy.

3) There is no accompaniment between the Sheikh's allowances with reliability, allowance means that the narrator is honest in receiving the hadith, or book of hadith master, not necessarily its hadith Shaykh is trustworthy. And while some Sheikh's allowances are without authority and Negus has weakened them.

4) There is no accompanied between the law and justice, because Balajma unfaithful substituent is permissible. Reliability is in protecting property other than trustworthiness and justice.

5) Narrator is the interpretation of personal Qomi named Abolfazl Abbas Ibn Muhammad Ibn al-Qasim, who is a disciple of Ali bin Ibrahim. He is unknown. And the interpretation alone does not belong to Gomi

6) Negus statement that "Narrated from trustworthy" by no means implies restriction, if it is said that Ja'far Ibn Bashir quoted unreliable narration, it does not mean that he did not quote from the non-trustworthy.

7) Those people who, Sheikh has named them as companions of Imam Sadiq (as), he only wanted to express their translations and biographies of their demands, but his intention of naming them had not been securitized.

8) There is no accompanied between the company and the authority, as we do not know all companions of the Prophet (PBUH) for their companionship.

9) Penitence can be done for the unfaithful believers. So if the likes of Shaykh Mufid or Sheikh Saduq asked penitence for someone, it does not mean their Securitized and in conjunction with the multiplicity of narratives, it may be the fake narrator have narrated Hadiths more than reliable narrators of the Imams (AS).

\section{References}

Al-Hilli, H. i. Y. (1411 AH). a summary of Alaqval, p.204, Dar Al Zakhaer, Najaf.

Alkhaghani, A. (1404 AH). Rejal Khaghani, P. 215. Islamic Propagation Office, Qom.

Hurr al-Amel, M. i. al-H. (n.d.). Wasā'il al-Shī'a, vol 27, p 150, Al al-Bayt Institute, Qom.

Khoei, A. (1994). Mu'jam Rijal al-Hadith, vol. 1, p. 59. Al saghafat Al Islamiyyah, Qom, Iran.

Qomi, A. b. I. (1984). Tafsir Al-Qomi. Daralktab, Qom.

Sadough, ibn Babawayh Muhammad ibn Ali. (1390 AH). Man la yahzarah al-Faqih, vol. 1, p. 4. Dar al kotob Islamiyah, Qom.

Sobhani, J. (1425). Koliat fi Ilm al-Rijal, pp. 170-168. Institute of Al nashr al islami Al tabaat al lejamat.

Tehrani, A. B. (1403 AH). Az-Zahraa al tasanif al shiah, p. 304, vol. 4299. Dar AL-Azva.

\section{Copyrights}

Copyright for this article is retained by the author(s), with first publication rights granted to the journal.

This is an open-access article distributed under the terms and conditions of the Creative Commons Attribution license (http://creativecommons.org/licenses/by/4.0/). 